\title{
The Way Young College Teachers Use Modern Educational Technology to Make Innovation in Classroom Education
}

\author{
Yan Li \\ Xi'an FanYi University \\ Xi'an, China 710105
}

\begin{abstract}
Modern educational technology has changed the traditional education mode. College teachers are the organizers of education and teaching and young and middle-aged teachers are the backbone of teaching. They have different levels of modern educational theories and techniques, which will produce different influences on teaching and practice activities. The application ability of modern educational technology is one of the most important professional abilities of modern teachers. It is of great significance for continuously improving teachers' ability to apply modern educational technology, innovating classroom teaching mode, promoting education and teaching reform, and improving the quality of education and teaching to deeply study the influence of modern educational technology on teaching mode.
\end{abstract}

Keywords-modern education technology; innovation; classroom education

\section{INTRODUCTION}

Teachers are the organizers of education and teaching as well as the main force of developing modern educational technology and promoting quality education. It should be recognized that teachers, especially young college teachers, are not only direct users and beneficiaries of modern educational technology, but also should teach students the concept of modern educational technology, cultivate students' awareness of applying modern educational technology for independent learning, and fully utilize modern educational technology to give full play to their advantages in teaching practice. Without the role of teachers, all advanced technologies and equipment will not play the real role. Therefore, the improvement of teachers' ability is a prerequisite for playing the role. Young teachers in colleges and universities should have the following abilities.

First is integration capability. Modern educational technology refers to the theory and practice that uses modern educational theory and modern information technology to promote the optimization of learning and teaching through the design, development, utilization, management and evaluation of educational processes and educational resources, and the training of technical quality of educational participants. Modern educational technology is not just modern technology (information technology), nor a modern educational theory, and even not the simple application of modern technology (information technology) in the field of education, but is the theoretical and practical activity that organically integrates modern information technology and curriculum and subject teaching with computer network and multimedia application technology as the core under the guidance of modern pedagogy and psychology theory to realize the optimization of teaching.

Second is innovation ability. Educational technology is not the simple application of technology, but it is based on the development needs of education and teaching. The theory and practice of innovative education is learned through theory. The young teachers in colleges and universities realizing the renewal of their own modern educational technology concepts and the acceptance of information is the transformation from "passive acceptance" to "active acceptance". They can organically integrate the modern information technology and the curriculum and subject teaching through the reform of the teaching model to improve the quality of teaching and achieve the continuous improvement of modern educational technology quality.

\section{THE INNOVATIVE QUALITIES OF INNOVATIVE} TEACHERS MAINLY INCLUDE THE FOLLOWING ASPECTS

\section{A. Innovative Ideas and Innovative Thought}

It is the teacher's ideological understanding of the view on educational goal, the view on student, the view on teacher, the view on method, the view on activity, and the evaluation view. For example, in the view on educational goals, the goal of cultivating students' high scores should be transformed to cultivating students' goals of creative desire and innovative ability. In the view on teachers, it is necessary to change the single knowledge imparters to the curriculum designers and developers and educational researchers. In the view on teaching methods, we must pay attention to learning process and learning ideas, change the infusing teaching into heuristic teaching, and change the information one-way transmission into the multi-directional transmission of information with students as the main body. 


\section{B. Innovative Awareness and Innovative Spirit}

This refers to the tendency and awareness of teachers to promote innovation, pursue innovation, and take pride in innovation; they are willing to engage in innovative activities and have courage in creating something new and original. Only under the guidance of strong sense of innovation can people generate strong motivation for innovation, establish innovation goals, and give full play to the potential of innovation and intelligence, and release the passion for innovation.

\section{Innovative Thinking and Innovative Ability}

Innovative thinking has five distinct characteristics: positively seeking differences, keen outsight, creative imagination, unique knowledge structure, and active inspiration. Innovative thinking is the key to the intelligent structure of the entire innovation activity and the core of innovation quality. Innovative ability refers to teachers' ability to create ideas and make inventions through bold exploration and practice based on predecessors' knowledge and experience. It is a kind of comprehensive intelligent quality of teachers, which is mainly reflected in teachers' multi-dimensional and reasonable intelligent structure, innovative thinking ability and ability of innovative activities, and creative teaching activities.

\section{Innovative Skills}

It is the behavioral skill, action ability and wisdom skill that reflects the innovation of innovative teachers, formed under the control and constraints of innovative intelligence and belonging to the working mechanism or working mode of innovative activities. Innovative skills mainly include the information processing ability, general work ability, handson ability or operation ability, the ability to master and apply innovative techniques, the expressive ability and performance ability of the innovation achievements, and the materialization ability of the innovation subject.

\section{E. Innovative Emotions and Innovative Personality}

The process of innovation is not just a pure intellectual process. It also needs to be driven by innovative emotions, such as lofty ideals, firm beliefs, and strong passion for innovation. Studies have shown that strong thirst for knowledge and strong curiosity can drive a person to be aggressive and engaged in innovative activities. Innovation should also be based on innovative personality. Innovative personality generally includes good personality characteristics such as bravery, humor, perseverance, tolerance, meticulousness, high adherence, and firm independence. For example, if teachers have no tolerance for creative students, they may be excluded by teachers. Without proper understanding and recognition, how can we expect extraordinary education and innovative education? It can be said that superior innovation emotions and good personality characteristics is the foundation and drive for forming and exerting innovative ability.
III. THE IMPACT OF MODERN EDUCATIONAL TECHNOLOGY ON INNOVATIVE CLASSROOM TEACHING MODE

The application of modern educational technology can promote the establishment of teachers' modern educational concepts and the application of modern educational theories; the second is to promote the research and application of modern educational technology; the third is to promote educational innovation and promote the reform and development of education and teaching; the fourth is to improve the quality of teaching and cultivate high-quality innovative talents that meet the requirements of modern social and economic development; fifth is promoting the modernization of education.

The economic and social development and modernization in the 21 st century put forward higher requirements for the quality of talents. Higher education must carry out education reform and education innovation. The starting point and the foothold of education reform and innovation are to meet the higher requirements of economic and social development for talents. The prerequisite is the establishment of teachers' modern educational concepts. The necessary condition is the application of modern science and technology with the main content of the computer-based information technology, multimedia technology and network technology in the field of education. To make education "face modernization", the modernization of education must be realized.

The application of modern educational technology is mainly reflected in the update of educational concept, the application of modern educational theory, the correlation with educational and teaching activities, the effect of educational and teaching activities, the application of teaching methods and innovation in teaching mode. The application of modern educational technology has profoundly changed the concept, content, means and management of education. The concrete manifestations are: changes in the mode of teaching and learning and the methods of teaching and learning; changes in the teaching environment and teaching process; changes in the concept and the form of teaching materials; changes in educational ideas and educational theories. The application of modern educational technology plays an extremely important role in education and teaching reform, innovative classroom teaching mode, and improvement of education and teaching effects. Its vitality lies in application and innovation, so it is necessary to work hard in application and innovate in the process of application.

\section{THE PERFORMANCE CHARACTERISTICS OF INNOVATIVE TEACHING MODE}

China's education circle is rapidly developing the "multimedia model" and "network model", which represent the development direction of educational technology as well as the future of educational technology. Computer network education has the irreplaceable advantages over traditional education and it has caused a profound change in the field of education, involving the innovation of school-running mode, curriculum, teaching content, teaching means, teaching 
methods and teaching models. The experience of educational practice shows that changing the traditional teacher-centered teaching structure and creating a new teaching structure can not only play the role of teacher guidance but also fully reflect the main role of students, so it will be the main goal of deepening the discipline teaching reform. According to the teaching activities formed by this reform goal, students become the main body of information processing, and teachers are the organizers, instructors and promoters of the teaching process. Modern educational technology is reflected in the creation of this new teaching model.

\section{A. Using Multimedia Information Integration Technology to Create Issues That Are Related to Reality and the Course Being Studied}

By taking advantage of Internet technology, it is possible to allow students to observe, think, and compare things, cultivate students' ability of independent thinking, give full play to students' initiative, enthusiasm and creativity in the learning process, and make students truly become the main body of information processing.

\section{B. Using Network Systems to Share Resources}

It is possible to allow students to obtain information from the multimedia teaching software, the local area network or the Internet, and get a variety of learning materials. Through inquiry and retrieval, the learning resources are used as objects for students to analyze and inquire, to help students understand the principles, and master the steps to analyze and solve problems, cultivating students' ability to learn independently.

\section{By Using Network Technology, Teachers and Students Can Talk to Each Other and Students Can Discuss in Groups and Communicate with Each Other}

It is suggested to design research-based learning activities, learning activities based on practical problems, and collaborative learning activities. Students analyze and evaluate the learning outcomes. Students are guided to master the ability to acquire, analyze, process, and communicate information.

\section{APPLYING MODERN EDUCATIONAL TECHNOLOGY TO MAKE INNOVATION IN TEACHING MODE}

With the application of modern science and technology such as information technology and digital technology in education, teachers and existing teaching have faced epochmaking challenges. Modern science and technology, such as information technology and digital technology, has begun to exert an important impact on the traditional teaching materials and teaching methods of the school, which has fundamentally changed the traditional role of teachers. The role of teachers is more inclined to "collaborators" and "leaders", which promotes teachers' educational concepts, behaviors, and corresponding teaching models to change. With the development of modern science and technology such as information technology, multimedia technology and digital technology, human society has entered the information age and digital age. The cultivation of talents must adapt to the development requirements of this informationization and digitization. The traditional teaching mode can no longer meet the development requirements of informationization and digitization and the development of modern educational technology such as information technology, network technology and multimedia technology provides a good condition for innovative classroom teaching mode.

The innovation of teaching mode must take the modern educational concept as the guide and rely on modern educational technology to realize two transformations and two breakthroughs in classroom teaching. The two transformations are as follows: first, the teacher-centered lecture-based classroom teaching is transformed to studentcentered lively classroom teaching with various forms. Second, the knowledge transference is transformed into the cultivation of focusing on thinking, practical ability and innovation spirit. The two breakthroughs are: first, teachers achieve heuristic teaching, and second is that students achieve research learning.

The innovation of teaching mode should be studentoriented and give full play to the main role of students, the teaching resources should organize teaching information according to the law of human association and the cognitive rules of students, and the design of teaching process should be guided by cognitive learning with the foothold of knowledge construction. Teaching is not only imparting knowledge, but also should pay attention to the cultivation of ability and comprehensive quality. The mastery of knowledge and the application of knowledge are important, but the application of knowledge is more important. Students must not only learn knowledge, but also learn how to learn. They should learn through active exploration, discovery and knowledge construction. Knowledge inheritance and knowledge innovation are valuable, but knowledge innovation is more valuable. It is necessary to train students to learn to survive, learn to learn, and learn to cooperate. The innovation of teaching mode changes the mode and methods of teaching and learning, changes the teaching environment and teaching methods and means, changes the concept of teaching materials and the form of teaching materials, and changes the educational concepts, educational thoughts and teaching theories.

The effective application of modern educational technology in education and teaching practice has created many new teaching modes, such as: network-based learning center teaching mode, computer-based auxiliary teaching mode, multimedia-based multimedia classroom teaching mode, individualized interactive learning mode based on multimedia computer network, virtual reality teaching mode based on multimedia computer network, teaching mode of professional subject characteristics based on information technology, distance learning mode based on internet, teacher-student interactive teaching mode based on information technology, practical teaching mode of information technology, the information-based situational inquiry teaching mode, the "self-study-discussion-practice" teaching mode based on the Internet, and so on. With the 
application of modern educational technology in the practice of education and teaching, classroom teaching models that meet the requirements of the development of the times will continue to emerge. However, the innovative teaching model can't be accomplished in an action, but it needs to be repeatedly tested through education and teaching practice before it can be finally established.

It is the requirement of modern science and technology and social development for education that teachers effectively use modern educational technology in the process of education and teaching, and innovate classroom teaching mode is the, which is also the need of education reform and development. The improvement of teachers' modern educational technology application ability will promote the effective application of modern educational technology, thus innovating new classroom teaching mode, improving teaching quality. The effective application of modern educational technology and the emergence of new classroom teaching mode will definitely promote the further improvement of teachers' ability to apply modern educational technology. Therefore, teachers' modern educational technology application ability is not only a key factor affecting the development and change of educational concepts, but also an important factor affecting the innovation of classroom teaching mode, and it is the core factor that affects the quality of education and teaching. This is an era of change and innovation as well as an era when science and technology are developing rapidly, competition is more intense, and society has higher requirements for the quality of talents. In particular, young teachers in colleges and universities must constantly learn, continuously improve the ability of modern educational technology, and constantly make innovation in classroom teaching models, to cultivate high-quality talents that meet the development requirements of the times.

\section{CONCLUSION}

In short, modern educational technology is the core driving force for the professional development of teachers, and it is the core content that penetrates into the professional development of teachers in colleges and universities. The impact of modern educational technology on education is profound and comprehensive. Modern educational technology refers to the theory and practice that design, develop, use, evaluate and manage the learning and teaching resources in the process of learning and teaching to promote the optimization of learning and teaching by using modern educational theory and modern information technology. Faced with the wave of modern educational technology, teachers must change their educational concepts and embrace innovative society with innovative education. The knowledge economy calls for innovative talents, and modern educational technology and quality education call for innovative teachers.

\section{REFERENCES}

[1] Zhang Jianhua, Song Liying. Modern education technology and classroom teaching model innovation [J]. Science and Technology Innovation Herald. 2012.02: 191-192. (in Chinese)

[2] Zhou Xiuying. Applying modern educational technology to innovate teaching mode $[\mathrm{J}]$. Journal of Beijing Institute of Planning Labour Administration. 2004.06: 58-59. (in Chinese)

[3] Hao Yanbo. The development of modern educational technology calls for innovative teachers [J]. Vocational Technology. 2004.05: 44-45. (in Chinese)

[4] Lan Zhenshi. How to improve teachers' quality in modern education technology [J]. Computer CD Software and Applications. 2012.02: 217-218. (in Chinese)

[5] Wang Dong et al. Analysis of the ability of university teachers in modern educational technology $[\mathrm{J}]$. Science \& Technology Information. 2008.10: 360. (in Chinese) 